\title{
INTEGRATED LEARNING AS A BASIS FOR QUALITY OF PREPARATION OF A MEDICAL SPECIALIST
}

\author{
Kenzhina Nazym Kasimgalievna, \\ Teacher of special disciplines, West Kazakhstan Higher Medical College, Uralsk, \\ Republic of Kazakhstan
}

\section{DOI: https://doi.org/10.31435/rsglobal_conf/30042021/7530}

\begin{abstract}
The major condition for medical education upgrading is a connection on the turn of various disciplines and competency- based approach of medical and pharmaceutical educational programmes together. The medical specialist's competence includes knowledge, proficiency, skills and their implementation in professional activity. [1]. Successful integrated leaning require a wide use of education technologies of practical and interactive type [2]. Integrated learning in medical education is of a special importance both in theory and practice. Timeliness is connected with the actual needs of the labour market due to fast changes in society. Integrated learning boosts student interest, improves analytical, comparative, synthesis skills. This kind of learning is successfully implemented in the USA and in European countries, where tendencies for economic, political, cultural, informational integration predominates.
\end{abstract}

Keywords: problem-based learning, integrated or inter-professional teaching, community-based education, elective studies, systematic or planned approach.

Goal of work. In order to integrate fundamental and clinical sciences, content of the educational programme shall be developed with immediate participation of the teachers of disciplines being integrated based on the analysis and solution of specific clinical issues.

Information and methods of research. Information on the topic shall include knowledge of basic and clinical disciplines in order to provide system-related evaluation and formation of future practical skills among the learners. The learners shall get a full understanding of the clinical situation and shall develop a systematic approach for provision of medical assistance to a patient. The main requirement of the labour market and practical healthcare while educating the specialist is a big gap between the real knowledge of the graduate and required practical skills: they lack for practical skills for working with medical equipment, as well as communication and stress management skills to real life events of practical healthcare. Discipline integration in the education system shall allow to solve today's objectives of education colleges and society in general. It's important to take into consideration that the fact of integrated connection between the disciplines has a little research and stated in a contradictive manner, contain lots of discrepancies in understanding the essence of these relations. In the West-Kazakhstan Higher Medical college popular are integrated lectures on horizontal and vertical lines of education: disciplines like Pathologic Physiology, Therapy, Surgery, Obstetrician affair, Hygiene and Evidentiary medicine, Pharmacology and Evidentiary medicine, the case is modelled for discussion of theoretical and practical issued between two specialists.

Foreseeing that a new education programme shall require new education methodical literature and other sources of information, on the initiative of the college management the teachers shall be able to make high quality records of their video-lectures and courses on the professionally equipped studies. To date each teacher has more than 500 lectures on you tube channels or e-mail clouds. Teaching material was considerably re-issued, grouped by practical skills and levels defined by special discipline teachers. Teaching material is based on the integrated learning model SPICES (studentcentered learning, problem-based learning, integrated or inter-professional teaching, community-based education, elective studies, and a systematic or planned approach, are now widely shared and accepted. The teacher acts as a facilitator.

The feedback of the most students (more than 82\%) proved that Teaching material helps the students to get prepared for the lessons. Since 2019asintegratedprogrammewasintroduced the WestKazakhstan Higher Medical college has transformed to a new digital platform College Smart Nation which takes into account all needs of the integrated learning programme, including schedule for each discipline where students could see discipline name and its objectives. This system has successfully 
started operating since March 2020, which allowed our college to painlessly and smoothly enter the distance learning mode.

Despite the transition to a different training system - the assessment model and the use of a new digital educational platform, the majority of students speak positively about the innovations. So, the feedback of the students of Medical assistant, Nurse, Pharmacy, Hygiene and Epidemiology, Obstetrician affair specialties shows high level of positive evaluation up to $84 \%$. The students participate is problem solving cases during integrated lectures.

In integrated lectures, students participate in the discussion of a problem situation, considering them in the context of various disciplines. In practical classes, using the integrated approach, they began to be introduced along the vertical of training, when conducting on one lesson two disciplines (Surgery and Pathologic Physiology, Pediatric affair and Obstetrician affair, Internal diseases and Pathologic Physiology, etc.)

The structure of the integrated lessons is as follows:

1) introduction part;

2) updating the basic knowledge necessary in the classroom;

3) organization of joint activities of a teacher of two disciplines;

4) consolidation of knowledge;

5) summing up.

The following procedure for the lesson is used:

- Monitor the students' knowledge at the start (testing)

- Each student's short reporting (thematic cases with physical observation, epidemiology, pathogenesis etc)

- Tutor's short resume with questions after the students' reporting (it's a key issue to give a constructive feedback)

- Final control (tests for understanding and use)

- Calculation of integrated evaluation in Excel (with the determination of the proportion of all types of grades for a lesson)

\section{Results of the research.}

During the training process students took an active part in problem solving and showed a logical approach in studying the proposed clinical case. Analysis of the clinical case was followed by interdisciplinary integration both horizontal and vertical which allowed to use basic theoretical knowledge with clinical and major. The students compared the obtained data with the academic one if they comply with clinical protocols and principles of evidence-based medicine. Feedback analysis proved that the students' skills, knowledge and critical thinking skills improved. Teachers note that the students became more motivated, improved learning and judgement skills as integrated approach allows to solve a specific clinical issue. Integrated learning is on the major methods of teaching of a higher school. Interdisciplinary connections are mediated by objective processes in education and healthcare. The students observe the interconnection between different subjects, understand their nature, can study the topic as a whole. They practice interactive way of thinking, get deep and versatile knowledge of different disciplines.

Summary. Application of the integrated learning principles in interdisciplinary practical lessons opens opportunities to create a clinical thinking among students of the medical colleges and provide a professional training of the specialists of a clinical profile. As compared with traditional learning interactive learning change the relationships between the teacher and the student: the student become more active than the teacher and the teacher's objective is to create conditions to get the students more involved in the process and become more initiative. Interactive learning firstly is a two way learning when student interacts with the teacher, and the students between themselves. Today introduction of the interactive methods of learning is one of the key areas of upgrading student education in modern education establishments.

This integrated learning is a key condition in education of the competent specialist taking into account requirements of the labour market and needs of the society. 


\section{REFERENCES}

1. Drake SM. Planning Integrated Curriculum theCall to Adventure. (Alexandria, VA: Association for Supervision and Curriculum Development, 1993).

2. Harden RM. The integration ladder Med. Educ. 2000:34:551-7.

3. Malik A.Sh., Hussain R. 2011 Twelve tips for developing an integrated curriculum. Medical teacher 33 : pp.99-104

4. Prideaux D. 2009. Integrated Learning. A practical guide for medical teachers. Churchill Livingstone. Elsevier. pp.181-186

5. Тайжанова Д.Ж., Романюк Ю.Л. Внедрение исследовательских проектов для самостоятельной работы обучающихся по дисциплине внутренние болезни // Международный журнал прикладных и фундаментальных исследований. - 2016. - №2. - С.97-98.

6. Лебедева О.В. Формирование методической компетентности учителя в области организации исследовательской деятельности // Вестник Нижегородского университета им. Н.И. Лобачевского. 2010. - №5(2). - C. 403-406.

7. Henk Dekker, Sylvia Walsarie Wolff. Re-inventing Research-Based Teaching and Learning. Paper prepared for presentation at the meeting of the European Forum for Enhanced Collaboration in Teaching of the European University Association in Brussels // Centre for Education and Learning (CEL). - 2016. - P.1-16. 